\title{
Parenteral oestrogen in the treatment of prostate cancer: a systematic review
}

\author{
G Norman', ME Dean', RE Langley², ZC Hodges', G Ritchie', MKB Parmar², MR Sydes², P Abel ${ }^{3}$ \\ and AJ Eastwood*,I
}

'Centre for Reviews and Dissemination, University of York, York YO 10 5DD, UK; ${ }^{2}$ Cancer Group, MRC Clinical Trials Unit, 222 Euston Road, London NWI 2DA, UK; ${ }^{3}$ Hammersmith Campus, Department of Surgery, Imperial College Faculty of Medicine, London WI 2 ONN, UK

The objectives of this study were to assess the effectiveness and safety of parenteral oestrogen in the treatment of prostate cancer, and to examine any dose relationship. A systematic review was undertaken. Electronic databases, published paper and internet resources were searched to locate published and unpublished studies with no restriction by language or publication date. Studies included were randomised controlled trials of parenteral oestrogen in patients with prostate cancer; other study designs were also included to examine dose-response. Study selection, appraisal, data extraction and quality assessment were performed by one reviewer and independently checked by another. Twenty trials were included in the review. The trials differed with regard to the included patients, formulation and dose of parenteral oestrogen, comparator used, outcome measures reported and the duration of follow-up. The results provide no evidence to suggest that parenteral oestrogen, in doses sufficient to produce castrate levels of testosterone, is less effective than luteinising hormone-releasing hormone (LHRH) or orchidectomy in controlling prostate cancer, or that it is consistently associated with an increase in cardiovascular mortality. Further well-conducted trials of parenteral oestrogen are required. A pilot randomised controlled trial comparing transdermal oestrogen to LHRH analogues in men with locally advanced or metastatic prostate cancer is underway in the United Kingdom.

British Journal of Cancer (2008) 98, 697-707. doi:I0.1038/sj.bjc.6604230 www.bjcancer.com

Published online 12 February 2008

(c) 2008 Cancer Research UK

Keywords: parenteral oestrogen; prostate cancer; systematic review

Prostate cancer is now the most common male cancer, with nearly 35000 new cases in the United Kingdom in 2004 (Cancer Research $\mathrm{UK}, 2007)$. When prostate cancer is not amenable to potentially curative therapy, the aim of treatment is to reduce circulating levels of androgens and/or block them from initiating intracellular signalling. This can be achieved either surgically (by orchidectomy) or medically (referred to as androgen deprivation therapy (ADT), e.g., by luteinising hormone-releasing hormone (LHRH) analogues with or without anti-androgens).

Androgen deprivation therapy is now used extensively and for prolonged periods of time, and concerns are increasing about long-term toxicity, particularly osteoporosis. For example, a recent longitudinal study has shown that $35 \%$ of men who received LHRH therapy for prostate cancer will experience at least one skeletal fracture in the first 7 years and 19\% will be diagnosed with osteoporosis/osteopaenia (Krupski et al, 2004). A number of clinical trials are underway to address whether adding a bonestrengthening agent, such as a bisphosphonate, to LHRH therapy would decrease the incidence of osteoporosis and other skeletalrelated events. Several other side effects of castration, including hot flushes, anaemia, and metabolic syndrome, are also increasingly recognised, although others such as cognitive dysfunction

*Correspondence: AJ Eastwood; E-mail: aje6@york.ac.uk Received 27 July 2007; revised 12 December 2007; accepted 7 January 2008; published online 12 February 2008 require further research to clarify their impact (Sharifi et al, 2005). It has recently been suggested that the use of ADT is associated with earlier onset of fatal myocardial infarction in men aged 65 years or above (D'Amico et al, 2007) and that in patients with locoregional prostate cancer it may be associated with an increase risk of cardiovascular disease not seen with orchidectomy (Keating et al, 2006). An alternative approach is to evaluate agents that are potentially as effective as, or more effective than, LHRH analogues in activity, for example, by achieving castrate levels of testosterone while avoiding some of the side effects of the castration syndrome.

Oral oestrogen therapy, such as diethylstilboestrol (DES), has been used as a method of ADT and is reported to be as effective as surgical orchidectomy or LHRH analogues in producing castrate levels of testosterone (Byar, 1973). It also avoids some of the side effects associated with the castration syndrome such as osteoporosis, osteoporotic fractures and hot flushes. However, large randomised studies highlighted the cardiovascular system (CVS) toxicities associated with this form of therapy, which occurred in $30-35 \%$ of patients treated with the highest doses (Byar, 1973). The CVS side effects of oral oestrogen have been attributed to firstpass hepatic metabolism (von Schoultz et al, 1989). In contrast, parenteral oestrogen (e.g., administered intravenously, intramuscularly or transdermally) avoids first-pass metabolism in the hepatic circulation system and is not expected to be associated with the same incidence of CVS toxicity.

Two small pilot studies have been conducted evaluating oestrogen patches for patients with prostate cancer (Ockrim 
et al, 2003; Morganstein et al, 2004). Neither study reported any serious adverse events, and minor adverse effects such as skin irritation were insufficient to cause discontinuation of treatment. In light of concerns about osteoporosis from current methods of $\mathrm{ADT}$ and preliminary evidence that oestrogen patches might be a useful therapy, a systematic review was undertaken. The aim of this review was to assess the existing research on the use of parenteral oestrogen in prostate cancer, compared with alternative treatments, in order to inform the design of a randomised clinical trial comparing oestrogen patches with LHRH analogues (Abel, ongoing).

\section{MATERIALS AND METHODS}

A systematic review protocol was developed with two principal aims: firstly, to investigate the clinical effectiveness and safety of parenteral oestrogen therapy in prostate cancer; and secondly, to examine any relationship between effectiveness or safety and oestrogen dose. Eighteen electronic databases, including MEDLINE, EMBASE and the Cochrane Central Register of Controlled Trials, were searched from inception to March 2004. Appropriate published paper and internet resources were also searched. (For a full list of sources searched and search terms used, see the full report by Dean et al, 2006.) The searches were updated in September 2007.

For the first review question, randomised controlled trials (RCTs) examining parenteral oestrogen in patients diagnosed with prostate cancer were included. Studies had to report at least one of the following outcome measures: overall survival, disease-free survival, disease progression, adverse events, quality of life, and economic costs. Inclusion criteria for the review question on dose-response were studies of any design that compared two or more doses of parenteral oestrogen in patients diagnosed with any stage of prostate cancer and reported at least one of the outcome measures listed above. Studies were assessed for inclusion and quality independently by two reviewers. The methodological quality of studies was evaluated independently using a modified form of the Jadad scale (Jadad et al, 1996). Data extraction was undertaken by one reviewer and independently checked by a second reviewer. All disagreements were resolved through consensus, and a third reviewer consulted where necessary. Multiple publications of a study were collated and extracted as a single study. No attempt was made to contact authors for missing data.

\section{RESULTS}

\section{Nature of the evidence}

The literature search produced 935 citations, from which 75 potentially relevant published papers were obtained. After full assessment, 22 reports of 17 studies with a total of 3627 randomised patients were included in the review of effectiveness and safety, and three studies with a total of 82 patients in the review of dose (Figure 1). Full details of all the studies (including secondary outcomes not reported here) are available in the CRD report (Dean et al, 2006). There was considerable variation between the trials, which differed with regard to the profile of the patients included, the dose and formulation of parenteral oestrogen employed, the comparator used; the outcome measures reported, and the duration of follow-up.

The updated searches produced 541 citations (additional to those located in the original search), from which 51 additional potentially relevant published papers were obtained. After full assessment, three further reports of two previously included studies were identified in the review of effectiveness and safety (Mikkola et al, 2005, 2007; Hedlund et al, 2007). Two of these were full papers (Mikkola et al, 2005, 2007) and one was an abstract

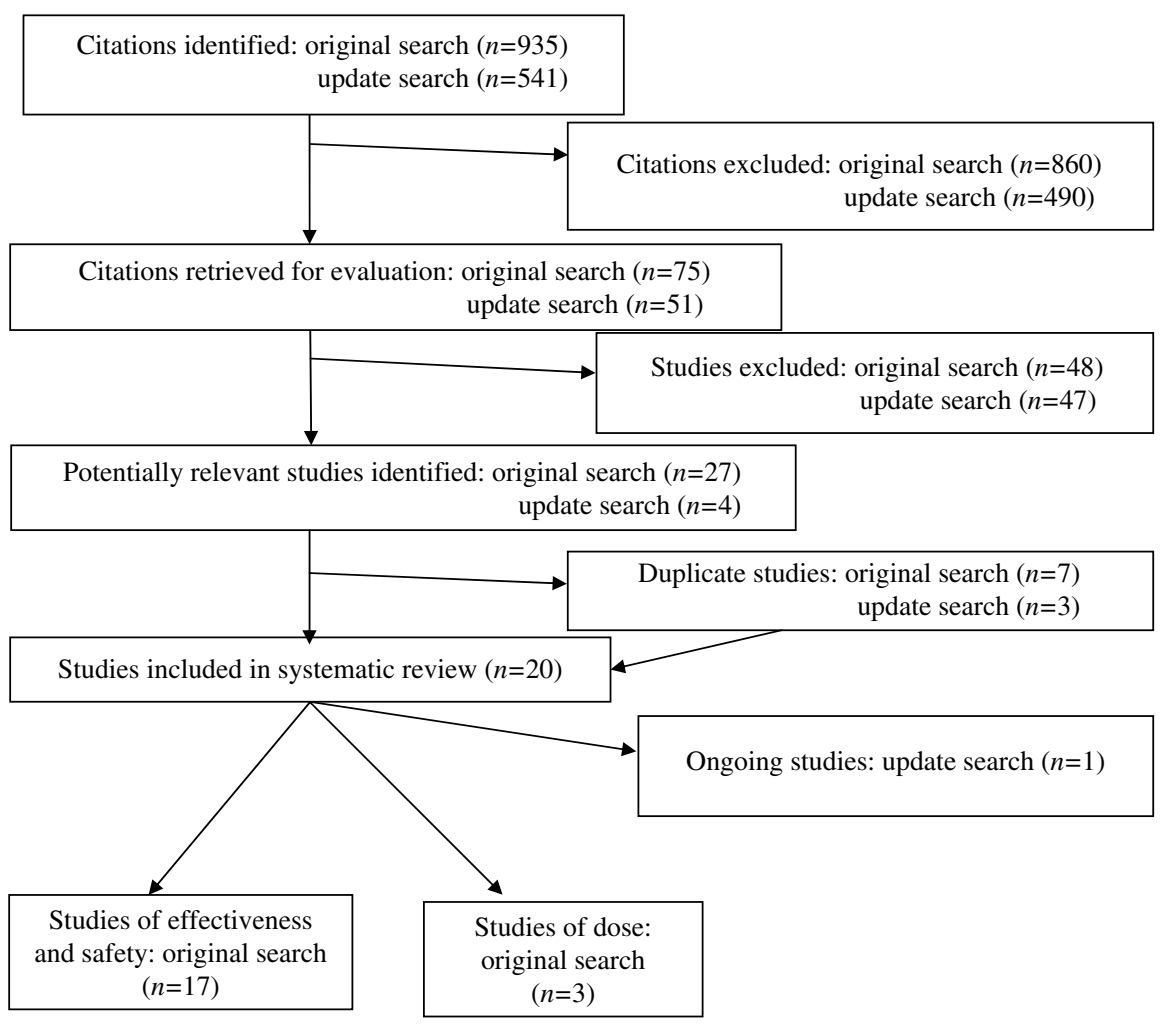

Figure I Study identification, retrieval and inclusion. 
(Hedlund et al, 2007). In addition, an ongoing trial was identified that compares transdermal oestrogen administered through patches with an LHRH analogue, but for which no outcome data are available (Abel, ongoing). No further studies were identified in the review of dose.

Therapies and routes of administration of the 17 studies included in the review of effectiveness and safety, parenteral oestrogen was given alone in 9 studies with a total of 2192 patients (Jacobi et al, 1980; Steg et al, 1983; Bishop et al, 1989; Haapiainen et al, 1990; Aro et al, 1993; Lukkarinen and Kontturi, 1994; Mikkola et al, 1998; Henriksson et al, 1999; Hedlund et al, 2002), combined with oral oestrogen in 7 studies with a total of 1247 patients (Andersson et al, 1980; Daehlin et al, 1986; Haapiainen et al, 1986; Henriksson and Edhag, 1986; Aro et al, 1988; Johansson et al, 1991a; Lundgren et al, 1995), and combined with doxorubicin in 1 study with 188 patients (Leaf et al, 2003). Intramuscular (i.m.) polyoestradiol phosphate (PEP) was used in 14 of the 17 included studies (Andersson et al, 1980; Daehlin et al, 1986; Haapiainen et al, 1986, 1990; Henriksson and Edhag, 1986; Aro et al, 1988, 1993; Bishop et al, 1989; Johansson et al, 1991a; Lukkarinen and Kontturi, 1994; Lundgren et al, 1995; Mikkola et al, 1998; Henriksson et al, 1999; Hedlund et al, 2002), and 7 of the 9 studies using parenteral oestrogen alone (Bishop et al, 1989; Haapiainen et al, 1990; Aro et al, 1993; Lukkarinen and Kontturi, 1994; Mikkola et al, 1998; Henriksson et al, 1999; Hedlund et al, 2002). The other studies used intravenous (i.v.) Stilboestrol (Leaf et al, 2003), topical 17- $\beta$-diethyl-oestradiol (Steg et al, 1983) and i.m. oestradiol undecylate (Jacobi et al, 1980). The three studies included in the review of dose all used i.m. PEP alone (Henriksson et al, 1988; Stege et al, 1988, 1989).

Only one study used any transdermal administration, comparing transdermal 17- $\beta$-diethyl-oestradiol administered as a cream with oral Stilboestrol (Steg et al, 1983). This small study $(n=42)$ was published more than 20 years ago and was poorly reported. The oestrogen dose of the topical ointment employed could not be accurately determined. It also used the surrogate outcome measure of urinary flow to assess tumour response. As this was the only identified evidence on the use of transdermal oestrogen, we focused on the higher quality evidence that was found on the use of i.m. PEP.

Pharmacokinetic studies suggest that a dose of at least $240 \mathrm{mg} \mathrm{month}^{-1}$ is required in order to produce sufficient oestradiol levels to rapidly suppress testosterone to castrate levels, in a manner similar to orchidectomy (Henriksson et al, 1999). Of the eight studies employing i.m. parenteral oestrogen alone, three used PEP doses of $240 \mathrm{mg} \mathrm{month}^{-1}$ (Mikkola et al, 1998; Henriksson et al, 1999; Hedlund et al, 2002), while the remainder employed $160 \mathrm{mg} \mathrm{month}^{-1}$ (Bishop et al, 1989; Haapiainen et al, 1990; Aro et al, 1993; Lukkarinen and Kontturi, 1994) or $100 \mathrm{mg} \mathrm{month}^{-1}$ (Jacobi et al, 1980). Seven studies combined PEP at $80 \mathrm{mg} \mathrm{month}^{-1}$ with oral ethinyl oestradiol at $150 \mu \mathrm{g} \mathrm{day}^{-1}$ (Andersson et al, 1980; Daehlin et al, 1986; Haapiainen et al, 1986; Henriksson and Edhag, 1986; Aro et al, 1988; Johansson et al, 1991a; Lundgren et al, 1995), and the remaining study that assessed parenteral oestrogen in combination used $1 \mathrm{~g}$ Stilboestrol i.v. every 2 weeks with $50 \mathrm{mg} \mathrm{m}^{-2}$ doxorubicin every 3 weeks (Leaf et al, 2003).

Patient populations There were differences between the trial participants in terms of their disease status, their prior treatment and their risk of CVS morbidity or mortality, including prior history of CVS complications. Some studies included only patients with metastatic disease, while others included only those with locally advanced prostate cancer. In some trials, there were stringent exclusion criteria for CVS history, while others did not exclude anyone on grounds of CVS health. Finally, some trials included only patients with newly diagnosed prostate cancer, while in others previous courses of non-hormonal treatment were permitted. Details of all the studies are presented elsewhere (Dean et al, 2006). Table 1 presents the study details for those studies which evaluated parenteral oestrogen alone at a dose of

Table I Study details of trials employing PEP at $240 \mathrm{mg}$ monthly

\begin{tabular}{|c|c|c|c|}
\hline Trial & Hedlund et al $(2002,2007)$ & Mikkola et al (1998, 2005, 2007) & Henriksson et al (1999) \\
\hline Study population & Advanced $(\mathrm{TO}-4, \mathrm{~N} \times, \mathrm{MI}$, grades $\mathrm{I}-3)$ & $\begin{array}{l}\text { Locally advanced }(\mathrm{T} 3-4, \mathrm{M} 0) \text { or metastatic } \\
(\mathrm{TI}-4, \mathrm{MI})\end{array}$ & Newly detected untreated advanced \\
\hline Recruitment period & December 1992 to June 1997 & January 1990 to March 1994 & Not reported \\
\hline $\begin{array}{l}\text { Patients recruited } \\
\text { (withdrawn) }\end{array}$ & $917(7)$ & $444^{\mathrm{a}}$ (not reported) & $33(0)$ \\
\hline \multirow[t]{8}{*}{ Disease status } & $\begin{array}{l}\text { T0 }(n=5) 0.5 \% \\
\text { TI }(n=33) 4 \% \\
\text { T2 }(n=146) \quad 16 \%\end{array}$ & & \\
\hline & T3 $(n=493) 54 \%$ & & T3 $(n=22) 66 \%$ \\
\hline & $\begin{array}{l}\text { T4 }(n=n=208) 23 \% \\
\text { (missing }(n=25))\end{array}$ & & $\mathrm{T} 4(n=11) 33 \%$ \\
\hline & All $\mathrm{MI} 100 \%$ & $\mathrm{~T} 3-4, \mathrm{MO}(n=244) 55 \%$ & $M 0(n=29) 88 \%$ \\
\hline & & $\mathrm{TI}-4, \mathrm{MI}(n=200) 45 \%$ & $M \mid(n=4) 12 \%$ \\
\hline & $\mathrm{GI}(n=136) \mid 5 \%$ & $\mathrm{GI}(n=\mid \mathrm{II}) 25 \%$ & \\
\hline & $\mathrm{G} 2(n=4 \mid 4) 45 \%$ & $\mathrm{G} 2(n=261) 59 \%$ & $\mathrm{G} 2(n=20) 61 \%$ \\
\hline & $\begin{array}{l}\text { G3 }(n=340) 40 \% \\
(\text { missing }(n=20))\end{array}$ & $\mathrm{G} 3(n=72) 16 \%$ & $\mathrm{G} 3(n=13) 39 \%$ \\
\hline \multirow[t]{3}{*}{ Follow-up } & Median follow-up: & 2 years, subgroup analyses at 3 and 10 years & 2 years \\
\hline & PEP 27.1 months & & \\
\hline & $\begin{array}{l}\text { Comparator: } 27.4 \text { months, brief report for } \\
12 \text { years }\end{array}$ & & \\
\hline Dose & $\begin{array}{l}240 \mathrm{mg} \text { every } 2 \text { weeks for } 2 \text { months } \\
\text { then } 240 \mathrm{mg} \mathrm{month}^{-1}\end{array}$ & $320 \mathrm{mg}$ initial dose then $240 \mathrm{mg} \mathrm{month}^{-1}$ & $\begin{array}{l}240 \mathrm{mg} \text { every } 2 \text { weeks for } 2 \text { months then } \\
240 \mathrm{mg} \mathrm{month}^{-1}\end{array}$ \\
\hline Comparator & Orchidectomy or combined androgen ablation & Orchidectomy & Orchidectomy \\
\hline Adjuvant therapy & No & Pretreatment breast irradiation & Pretreatment breast irradiation \\
\hline Cardiovascular criteria & $\begin{array}{l}\text { No myocardial or cerebral infarct I month or } \\
\text { less before the start of study }\end{array}$ & No symptomatic coronary heart disease & $\begin{array}{l}\text { Patients with previous cardiovascular } \\
\text { disease were included }\end{array}$ \\
\hline Study quality & High & Randomisation poorly reported & Randomisation poorly reported \\
\hline
\end{tabular}

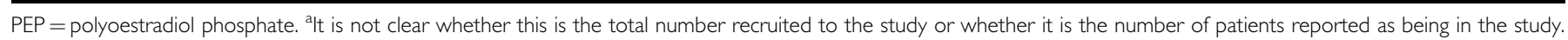


Table 2 Included studies assessing parenteral oestrogen alone

\begin{tabular}{|c|c|c|c|c|c|c|c|}
\hline Study & $N$ & Comparator & Follow-up & All-cause mortality & $\begin{array}{l}\text { Prostate cancer } \\
\text { mortality }\end{array}$ & $\begin{array}{l}\text { Cardiovascular adverse } \\
\text { events }\end{array}$ & Study quality \\
\hline \multicolumn{8}{|c|}{ PEP at $240 \mathrm{mg}$ monthly ${ }^{\mathrm{a}}$} \\
\hline $\begin{array}{l}\text { Hedlund et al } \\
(2002,2007)\end{array}$ & 917 & $\begin{array}{l}\text { Comparator: triptorelin } \\
3.75 \text { mg month } \\
\text { i.m. }+ \text { flutamide } 250 \mathrm{mg} \\
\text { t.i.d., p.o. }(n=298) \\
\text { or optionally } \\
\text { orchidectomy } \\
(n=159)\end{array}$ & $\begin{array}{l}\text { Median: } \\
\text { PEP: } 27.1 \text { months } \\
\text { Comparator: } 27.4 \\
\text { months (brief report at } \\
12 \text { years) }\end{array}$ & $\begin{array}{l}\text { PEP: } 277 / 455 \text { (60.9\%) } \\
\text { Comparator: } 279 / 455 \\
(61.3 \%)\end{array}$ & $\begin{array}{l}\text { PEP: } 239 / 455(52.5 \%) \\
\text { Comparator: } 252 / 455 \\
(55.4 \%)\end{array}$ & $\begin{array}{l}\text { PEP: 80/455 (17.6\%), } \\
23 \text { fatal }(5.1 \%) \\
\text { Comparator: } 59 / 455 \text { (13.0\%), } \\
23 \text { fatal }(5.1 \%)\end{array}$ & $\begin{array}{l}\text { High quality, blind outcome } \\
\text { assessment, central } \\
\text { randomisation }\end{array}$ \\
\hline $\begin{array}{l}\text { Mikkola et al } \\
(1998,2005 \\
2007)\end{array}$ & 444 & Orchidectomy & $\begin{array}{l}2 \text { years; subgroup } \\
\text { analyses at } 3 \text { and } 10 \\
\text { years }\end{array}$ & $\begin{array}{l}2 \text { years: } \\
\text { PEP: 27/227 (I I.9\%) } \\
\text { Orchidectomy: 23/217 } \\
\text { (10.6\%) } \\
10 \text { years: } \\
\text { MO: PEP: } 97 / 125 \\
\text { (77.6\%) } \\
\text { Orchidectomy: } 88 / 119 \\
\text { (73.9\%) } \\
\text { MI: PEP: } 94 / 102 \\
\text { (92.2\%) } \\
\text { Orchidectomy: } 91 / 98 \\
\text { (92.9\%) }\end{array}$ & $\begin{array}{l}2 \text { years: } \\
\text { PEP: } 8 / 227 \text { (3.5\%) } \\
\text { Orchidectomy: } 7 / 217 \\
\text { (3.2\%) } \\
\text { 10 years: MO: PEP: } 44 / 125 \\
\text { (35.2\%) Orchidectomy: } 47 / \\
\text { 1 19 (39.5\%); } \\
\text { MI: PEP: } 76 / 102 \text { (74.5\%) } \\
\text { Orchidectomy: } 61 / 98 \\
\text { (62.2\%) }\end{array}$ & 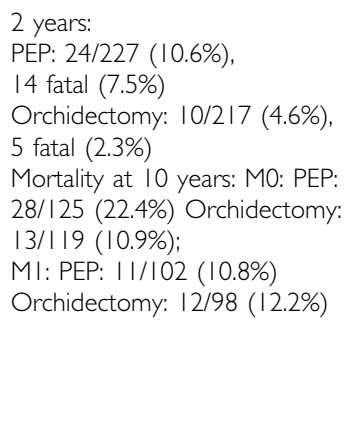 & $\begin{array}{l}\text { Adequate study design but } \\
\text { inadequate reporting of } \\
\text { withdrawals }\end{array}$ \\
\hline $\begin{array}{l}\text { Henriksson et al } \\
\text { (1999) }\end{array}$ & 33 & Orchidectomy & 2 years & $\begin{array}{l}\text { PEP: 0/17 (0\%) } \\
\text { Orchidectomy: I/I6 } \\
\text { (6.2\%) }\end{array}$ & Not reported & $\begin{array}{l}\text { PEP: I/I7 (5.9\%) } \\
\text { Orchidectomy: 4/I6 (25.0\%) }\end{array}$ & $\begin{array}{l}\text { Pilot study, method of } \\
\text { randomisation not } \\
\text { described }\end{array}$ \\
\hline \multicolumn{8}{|c|}{ PEP at $160 \mathrm{mg}$ monthly ${ }^{\mathrm{a}}$} \\
\hline $\begin{array}{l}\text { Lukkarinen and } \\
\text { Kontturi (1994) }\end{array}$ & 236 & $\begin{array}{l}\text { LHRH: goserelin s.c. } \\
\text { depot injection } 3.6 \mathrm{mg} \\
\text { per } 28 \text { days }\end{array}$ & $\begin{array}{l}\text { Mean: } \\
\text { PEP: } 23 \text { months } \\
\text { LHRH: } 26 \text { months }\end{array}$ & $\begin{array}{l}\text { PEP: I3/I07 (12.1\%) } \\
\text { LHRH: I4/I29 (10.8\%) }\end{array}$ & $\begin{array}{l}\text { PEP: } 3 / 107 \text { (2.8\%) } \\
\text { LHRH: } 3 / 129(2.3 \%)\end{array}$ & $\begin{array}{l}\text { PEP: 23/I07 (21.5\%), } \\
7 \text { fatal (6.5\%) } \\
\text { LHRH: } 13 / 129 \text { (10.1\%), } \\
8 \text { fatal (6.2\%) }\end{array}$ & $\begin{array}{l}\text { Inadequate reporting of } \\
\text { withdrawals }\end{array}$ \\
\hline $\begin{array}{l}\text { Haapiainen et al } \\
\text { (1990) }\end{array}$ & 200 & Orchidectomy & $>2$ years & $\begin{array}{l}\text { PEP: } 12 / 125(9.6 \%) \\
\text { Orchidectomy: } 6 / 75 \\
\text { (8.0\%) }\end{array}$ & $\begin{array}{l}\text { PEP: } 6 / 125 \text { (4.8\%) } \\
\text { Orchidectomy: 5/75 (6.7\%) }\end{array}$ & $\begin{array}{l}\text { CVS mortality: } \\
\text { PEP: 2/I25 (1.6\%) } \\
\text { Orchidectomy: I/75 (1.3\%) } \\
\text { Non-fatal events NR }\end{array}$ & $\begin{array}{l}\text { Inadequate reporting of } \\
\text { withdrawals }\end{array}$ \\
\hline $\begin{array}{l}\text { Aro et al (1988, } \\
1989,1993)\end{array}$ & 147 & $\begin{array}{l}\text { LHRH: buserelin } 6.6 \mathrm{mg} \\
\text { per } 8 \text { weeks; implant } \\
\text { s.c. }\end{array}$ & 3 years & NR & NR & $\begin{array}{l}\text { PEP: } 5 / 70(7.1 \%), 4 \text { fatal }(5.7 \%) \\
\text { LHRH: } 6 / 77(7.8 \%), 4 \text { fatal } \\
(5.2 \%)\end{array}$ & Adequate study design \\
\hline $\begin{array}{l}\text { Bishop et al } \\
(1989)\end{array}$ & 117 & Orchidectomy & NR & NR & NR & $\begin{array}{l}\text { PEP: } 8 / 61 \text { ( } 13.1 \%), 3 \text { fatal } \\
\text { (4.9\%) } \\
\text { Orchidectomy: } 4 / 56 \text { (7.1\%), } \\
\text { all fatal }\end{array}$ & $\begin{array}{l}\text { Insufficient information to } \\
\text { assess }\end{array}$ \\
\hline \multicolumn{8}{|c|}{ Oestradiol undecylate at $100 \mathrm{mg}$ monthly } \\
\hline $\begin{array}{l}\text { Jacobi et al } \\
\text { (1980) }\end{array}$ & $42^{\circ}$ & $\begin{array}{l}\text { Cyproterone acetate } \\
300 \text { mg week }^{-1} \text { i.m. }\end{array}$ & $N R$ & NR & NR & $\begin{array}{l}\text { PEP: } 16 / 21 \text { ( }(76.2 \%), \\
2 \text { fatal }(9.5 \%) \\
\text { Cyproterone: } 0 / 21 \text { ( }(0 \%)\end{array}$ & $\begin{array}{l}\text { Insufficient information to } \\
\text { assess }\end{array}$ \\
\hline
\end{tabular}


$240 \mathrm{mg}$ month ${ }^{-1}$. It shows the variation in the patient populations between the studies, for example, all patients in the Hedlund trial had metastatic disease (Hedlund et al, 2002), compared with $45 \%$ in the Mikkola trial (Mikkola et al, 1998) and $12 \%$ in the Henriksson trial (Henriksson et al, 1999).

Study quality None of the studies met all of the quality criteria; the majority of the studies were not reported in sufficient detail to allow full assessment of their methodological quality (Dean et al, 2006). In particular, the methods of randomisation and blinding were rarely described; only two reports contained enough detail to confirm that the method of randomisation was appropriate (Aro et al, 1993; Hedlund et al, 2002), one of which also reported that randomisation was concealed (Aro et al, 1993). Only one study reported that cardiovascular outcomes were assessed by a cardiologist blinded to the interventions (Hedlund et al, 2002).

\section{Trials using PEP at $240 \mathrm{mg} \mathrm{month}^{-1}$}

In this report, emphasis is given to the three studies, including a total of 1394 patients, that used PEP at the biological minimally effective dose. The results of these studies are given in Table 2 . The largest most recent study $(n=917)$ was of good quality (Hedlund et al, 2002). This study randomised patients with T0-4 NX M1 prostate cancer to either PEP twice a month for 2 months and thereafter monthly, or to combined androgen blockade (flutamide and LHRH analogue or on an optional basis bilateral orchidectomy). A second study $(n=444)$, by Mikkola et al $(2007,1998)$, randomised patients with T3-4 M0 or T1-4 M1 prostate cancer to either PEP or orchidectomy, and this study was of reasonable quality. The third study was a small phase II study, which randomised patients with newly diagnosed advanced prostate cancer to either PEP or orchidectomy (Henriksson et al, 1999).

Overall mortality The Hedlund study had high overall mortality (7 years after the start of the trial, with a median follow-up of 27 months, $61 \%$ of all patients had died) (Hedlund et al, 2002). There was no evidence of any difference in overall mortality between the treatment groups $(\mathrm{RR}=0.99,95 \% \mathrm{CI}: 0.90,1.10 ; \quad P=0.89)$ (Figure 2). This finding was confirmed by a brief report of a subsequent evaluation of data at 12-year follow-up, at which point $94 \%$ of patients had died (Hedlund et al, 2007). In the Mikkola trial, $76 \%$ of $\mathrm{M} 0$ and $93 \%$ of M1 patients had died at 10 -year follow-up (Mikkola et al, 2007). The 2-year evaluation found no evidence of a difference in overall mortality between the treatment groups $(\mathrm{RR}=1.12,95 \% \mathrm{CI}: 0.66,1.90 ; P=0.67$ ) (Mikkola et al, 1998). Subgroup analysis using a Cox proportional hazards model at 10-year follow-up also showed no evidence of a difference between the PEP and the orchidectomy arm in either the M0 or the M1 patients (M0: RR $=1.23,95 \%$ CI: $0.92,1.64 ; P=0.17$; 1 : $\mathrm{RR}=0.95,95 \% \mathrm{CI}: 0.70,1.27 ; P=0.70$ ) (Mikkola et al, 2007). The RRs calculated from raw data presented in the publication are shown in Figure 3. The Henriksson trial reported only one death in the orchidectomy group and none in the PEP group (Henriksson et al, 1999).

Prostate cancer mortality The majority of mortality in the Hedlund study was reportedly due to prostate cancer; there was no evidence of any difference between treatment groups in the occurrence of cancer deaths $(\mathrm{RR}=0.95,95 \% \mathrm{CI}$ : 0.84, 1.07; $P=0.39$ ) (Hedlund et al, 2002) (Figure 4). This finding was confirmed by a brief report of a subsequent evaluation (Hedlund et al, 2007). There was also no evidence of a difference in prostate cancer mortality in the two arms of the Mikkola trial at 2 years ( $\mathrm{RR}=1.09,95 \% \mathrm{CI}: 0.40,2.96 ; P=0.86$ ) (Mikkola et al, 1998); subsequent subgroup analysis using a Cox proportional hazards model at 10-year follow-up also showed no difference in diseasespecific mortality in either M0 or M1 patients (M0: RR $=1.14,95 \%$ 


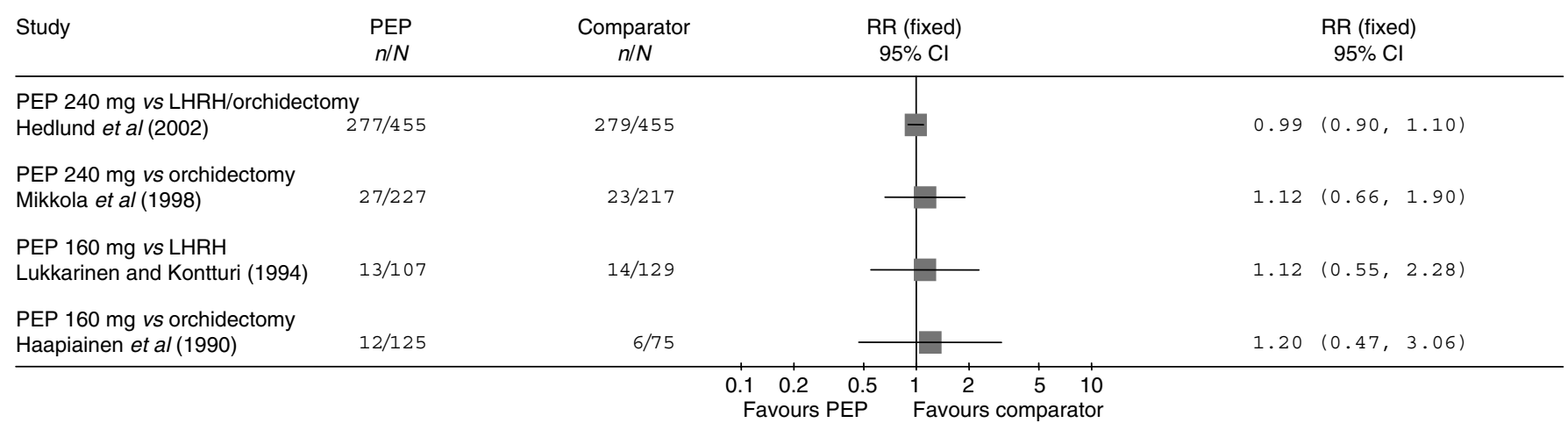

Figure 2 Overall mortality. Trials included in the figure are those where the parenteral oestrogen was PEP alone and for which data were fully reported. It should be noted that the follow-up times reported were not entirely uniform; where data for multiple time points were available those closest to 2 years are presented. Trials with zero events in any arm are not included in the figure.

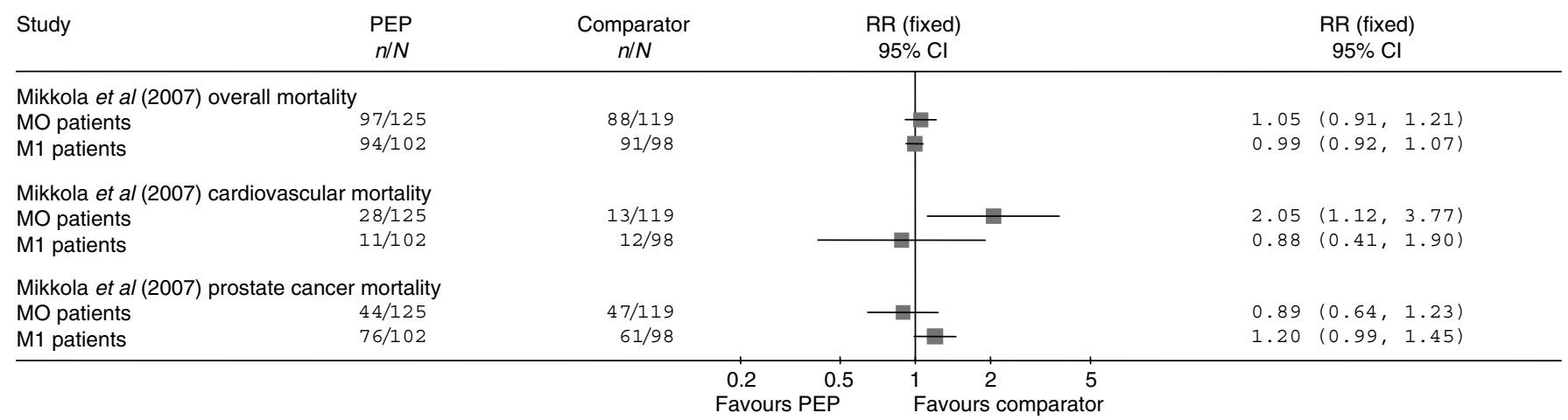

Figure 3 Overall, CVS and prostate cancer mortality at I0-year follow-up in the Mikkola trial for M0 and MI subgroups. RRs shown are calculated from raw data presented in the publication and differ from those reported in the text, which were extracted from the Cox proportional hazards model reported.

CI: $0.75,1.73 ; P=0.55 ; \mathrm{M} 1: \mathrm{RR}=1.07,95 \% \mathrm{CI}: 0.76,1.50 ; P=0.72)$ (Mikkola et al, 2007). RRs calculated from raw data presented in the publication are shown in Figure 3. The small study by Henriksson et al (1999) reported no deaths due to prostate cancer.

CVS mortality There was no evidence of a difference in CVS mortality in the Hedlund trial $(\mathrm{RR}=1.00,95 \% \mathrm{CI}$ : 0.57, 1.76; $P=1.00$ ) (Hedlund et al, 2002) (Figure 4). This finding was confirmed by a brief report of a subsequent evaluation (Hedlund et al, 2007). The Mikkola trial showed an increased level of CVS mortality in the PEP arm, although this was of borderline statistical significance $(\mathrm{RR}=2.68,95 \% \mathrm{CI}: 0.98,7.31 ; P=0.05)$ (Mikkola et al, 1998). Subsequent subgroup analyses using a Cox proportional hazards model found this increase to be confined to M0 patients $(\mathrm{RR}=3.52,95 \% \mathrm{CI}: 1.65,7.54 ; P=0.001)$; the subgroup with M1 disease showed no difference between the PEP and the orchidectomy groups $(\mathrm{RR}=0.92,95 \% \mathrm{CI}: 0.36,2.36 ; P=0.86)$ (Mikkola et al, 2007). RRs calculated from raw data presented in the publication are shown in Figure 3. In this study, the authors retrospectively classified patients into those at high risk of CVS complications due to pretreatment vascular disease (patients with previous coronary heart disease, cerebral infarction, transient ischaemic attack or intermittent claudication), those with other pretreatment diseases associated with the risk of CVS events (patients with previous diabetes mellitus, hypertension, cardiac heart failure or rheumatoid arthritis), and those without any of the above pretreatment diseases (Mikkola et al, 2005). Within both the M0 and the M1 patient groups, the proportional hazards model found that the excess mortality in the PEP treatment arm was higher in those classified as having pretreatment vascular disease (M0: RR $=3.48,95 \%$ CI: $1.63,7.44 ; P=0.001 ; \mathrm{M} 1: \mathrm{RR}=3.13,95 \%$ CI: $1.09,9.00 ; P=0.035)$, but those with other pretreatment disease associated with CVS risk did not have significantly increased mortality $(\mathrm{M} 0: \mathrm{RR}=1.64,95 \% \mathrm{CI}: 0.59,4.57 ; P=0.34 ; \mathrm{M} 1$ : $\mathrm{RR}=1.63,95 \% \mathrm{CI}: 0.40,6.57 ; P=0.49$ ) (Mikkola et al, 2007). There were no CVS deaths reported in the Henriksson trial (Henriksson et al, 1999).

CVS morbidity In contrast to the evidence on mortality, it appeared that CVS morbidity may occur at an increased rate in the PEP groups. In the Hedlund trial, this difference was statistically significant $(\mathrm{RR}=1.58,95 \% \mathrm{CI}: 1.07,2.35 ; P=0.02)$ (Hedlund et al, 2002) (Figure 5). In particular, the incidence of both ischaemic heart disease $(\mathrm{RR}=3.40,95 \% \mathrm{CI}: 1.27,9.14 ; P=0.02)$ and heart decompensation ( $\mathrm{RR}=2.22$, 95\% CI: $1.02,4.83 ; P=0.04)$ was significantly higher in the PEP arm. This finding was confirmed by a brief report of a subsequent evaluation (Hedlund et al, 2007). The Mikkola trial also initially reported higher levels of CVS morbidity in the PEP arm than the orchidectomy arm, but this difference was not statistically significant ( $\mathrm{RR}=1.91,95 \% \mathrm{CI}: 0.66,5.50 ; P=0.23$ ) (Mikkola et al, 1998). However, subsequent subgroup analyses at 36-month follow-up revealed that there was a significantly greater incidence of CVS complications, including mortality, in the M0 patients $(\mathrm{RR}=3.40,95 \% \mathrm{CI}: 1.34,8.59 ; P=0.01)$ but not in the M1 patients ( $\mathrm{RR}=1.55,95 \% \mathrm{CI}: 0.61,3.97 ; P=0.36)$ (Mikkola et al, 2005). As with CVS mortality, a Cox proportional hazards model 


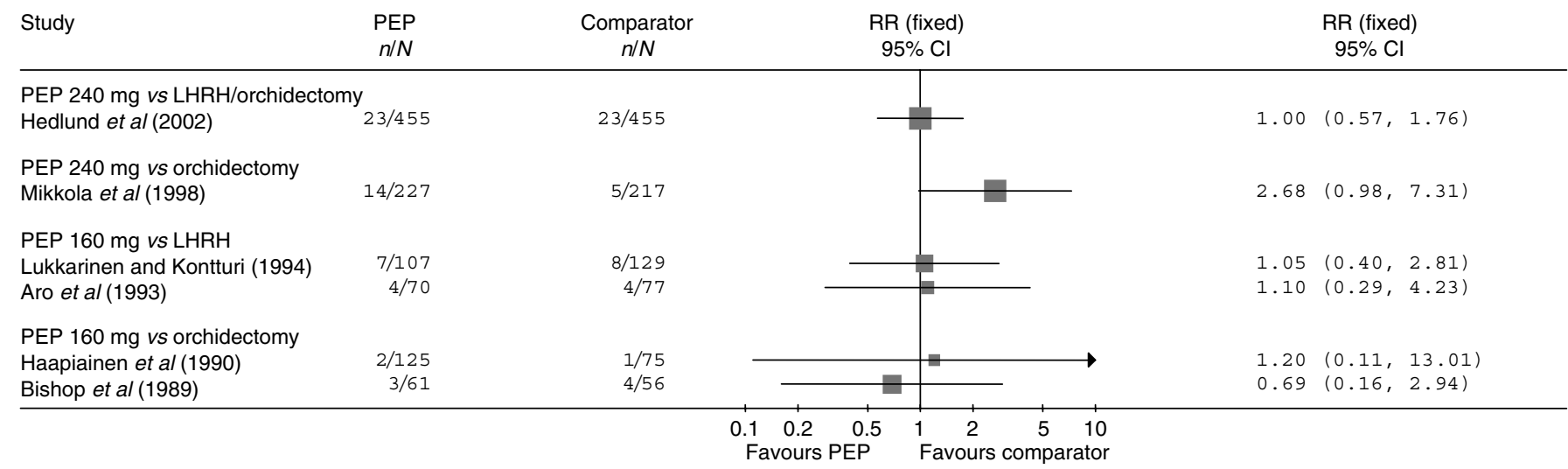

Figure 4 CVS mortality. Trials included in the figure are those where the parenteral oestrogen was PEP alone and for which data were fully reported. It should be noted that the follow-up times reported were not entirely uniform; where data for multiple time points were available those closest to 2 years are presented. Trials with zero events in any arm are not included in the figure.

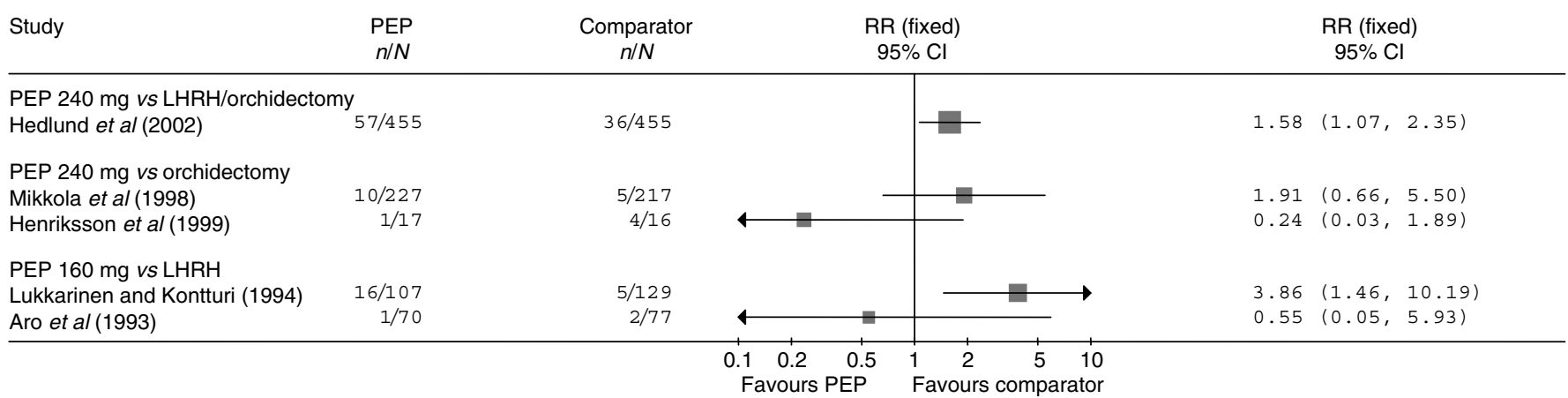

Figure 5 CVS morbidity. Trials included in the figure are those where the parenteral oestrogen was PEP alone and for which data were fully reported. It should be noted that the follow-up times reported were not entirely uniform; where data for multiple time points were available those closest to 2 years are presented. Trials with zero events in any arm are not included in the figure.

found that the complication rate was significantly increased in those M0 patients with pretreatment vascular disease $(\mathrm{RR}=4.71$, 95\% CI: $1.69,13.09 ; P=0.003)$, but not in those with other pretreatment disease associated with CVS risk $(\mathrm{RR}=2.25,95 \% \mathrm{CI}$ : $0.65,7.83 ; P=0.20$ ) (Mikkola et al, 2005). The Henriksson trial found more events in the orchidectomy group (4 out of 16) than in the PEP group (1 out of 17) (Henriksson et al, 1999).

\section{Trials using lower doses of parenteral oestrogen alone}

Five trials used PEP or a similar preparation at 160 or $100 \mathrm{mg} \mathrm{month}^{-1}$. The results are shown in Table 2 . There was no evidence of a statistically significant difference between treatment groups in either overall or prostate cancer mortality in the two studies that reported these outcomes. Cardiovascular mortality was reported by all five trials and did not differ significantly between treatment groups in any of the trials ( $P$-values ranged from 0.29 to 0.91 ). Cardiovascular morbidity was reported in four trials (Jacobi et al, 1980; Bishop et al, 1989; Aro et al, 1993; Lukkarinen and Kontturi, 1994), and in only one, there was a statistically significant increase in the PEP group compared to the LHRH group ( $R R=3.86,95 \%$ CI: $1.46,10.19 ; P=0.01)$ (Lukkarinen and Kontturi, 1994).

Trials using parenteral oestrogen combined with oral oestrogen or doxorubicin $(\mathrm{PEP}+)$

Seven trials with a total of 1256 patients used PEP (i.m.) at $80 \mathrm{mg} \mathrm{month}^{-1}$ in combination with $150 \mu \mathrm{g} \mathrm{day}^{-1}$ oral oestradiol (Andersson et al, 1980; Daehlin et al, 1986; Haapiainen et al, 1986;
Henriksson and Edhag, 1986; Aro et al, 1988; Johansson et al, 1991a; Lundgren et al, 1995). One trial with 188 patients used Stilboestrol i.v. in combination with doxorubicin (Leaf et al, 2003). The results are given in Table 3. There was no evidence of a statistically significant difference between treatment groups in overall, prostate cancer or cardiovascular mortality in any of the studies that reported these outcomes. However, cardiovascular morbidity was higher in the PEP + group than the comparator group for a number of studies; in particular, in one trial, recruitment to the PEP + arm was terminated early due to the high number of cardiovascular events (Lundgren et al, 1995).

\section{Dose}

Three studies with a total of 82 patients examined different doses of PEP (Henriksson et al, 1988; Stege et al, 1988, 1989). All were small and of uncertain or poor quality; one was a non-randomised trial (Henriksson et al, 1988). None of the studies reported mortality and in none of the studies any CVS events were reported (Table 4).

\section{DISCUSSION}

This review of effectiveness and safety focused on the randomised evidence related to the use of i.m. PEP; only one small poor quality study of transdermal oestrogen cream was identified. The included trials were generally poorly reported or of poor quality. Nine studies evaluated parenteral oestrogen administered as monotherapy, and three of these used a clinically relevant dose of PEP 
Table 3 Included studies assessing parenteral oestrogen in combination with oral oestrogen or doxorubicin (PEP+)

\begin{tabular}{|c|c|c|c|c|c|c|c|}
\hline Study & $\mathbf{N}$ & Comparator & Follow-up & All-cause mortality & $\begin{array}{l}\text { Prostate cancer } \\
\text { mortality }\end{array}$ & $\begin{array}{l}\text { Cardiovascular adverse } \\
\text { events }\end{array}$ & Study quality \\
\hline \multicolumn{8}{|c|}{ PEP at $80 \mathrm{mg}$ monthly plus oral ethinyl oestradiol at I $50 \mu \mathrm{g}$ daily $(P E P+)^{\mathrm{a}}$} \\
\hline $\begin{array}{l}\text { Lundgren et al } \\
\text { (1995) }\end{array}$ & 285 & $\begin{array}{l}\text { ( I) Estramustine phosphate } \\
280 \text { mg b.i.d., p.o. } \\
\text { (2) Surveillance, endocrine } \\
\text { treatment on progression }\end{array}$ & $\geqslant 9$ years & $\begin{array}{l}\text { PEP+: } 35 / 66 \text { (53.0\%) } \\
\text { Estramustine: } 40 / 74(54.1 \%) \\
\text { Surveillance: 53/88 (60.2\%) }\end{array}$ & $\begin{array}{l}\text { PEP+: } 8 / 66(12.1 \%) \\
\text { Estramustine: } 13 / 74 \\
\text { (17.6\%) } \\
\text { Surveillance: } 25 / 88 \text { (28.4\%) }\end{array}$ & $\begin{array}{l}\text { Events leading to withdrawal: } \\
\text { PEP+: } 37 / 66(56.1 \%) \\
\text { Estramustine: } 30 / 74(40.5 \%) \\
\text { Surveillance: } 11 / 88(21.5 \%)\end{array}$ & $\begin{array}{l}\text { Large number of patients } \\
\text { withdrawn and excluded from } \\
\text { analysis. Recruitment to PEP+ } \\
\text { arm terminated early due to } \\
\text { high CVS event rate }\end{array}$ \\
\hline $\begin{array}{l}\text { Haapiainen et al } \\
(1986,1991)\end{array}$ & 277 & Orchidectomy & 5 years & $\begin{array}{l}\text { PEP+: I0I/I46 (69.1\%) } \\
\text { Orchidectomy: 86/I3I (65.6\%) }\end{array}$ & $\begin{array}{l}\text { PEP+: } 45 / 146 \text { (30.8\%) } \\
\text { Orchidectomy: } 47 / 131 \\
\text { (35.9\%) }\end{array}$ & $\begin{array}{l}\text { CVS mortality: } \\
\text { PEP+: } 35 / 146 \text { (24.0\%) } \\
\text { Orchidectomy: } 24 / 131 \text { (18.3\%) }\end{array}$ & $\begin{array}{l}\text { Inappropriate randomisation } \\
\text { (by date of birth) }\end{array}$ \\
\hline $\begin{array}{l}\text { Andersson et al } \\
\text { (1980) }\end{array}$ & 263 & $\begin{array}{l}\text { Estramustine phosphate } \\
840 \mathrm{mg}^{-1}{ }^{-1} \text { b.i.d., p.o. }\end{array}$ & $\geqslant 2$ years & NR & NR & $\begin{array}{l}\text { No significant difference } \\
\text { between groups (values not } \\
\text { reported) }\end{array}$ & $\begin{array}{l}\text { Trial groups not clearly } \\
\text { explained }\end{array}$ \\
\hline Aro et al (1988) & $|5|$ & $\begin{array}{l}\text { (1) Orchidectomy } \\
\text { (2) Radiotherapy } 40 \text { Gy } \\
\text { (whole pelvis), } 26 \text { Gy (prostate) } \\
\text { over } 9 \text { weeks including } \\
3 \text { weeks rest }\end{array}$ & 4 years & $\begin{array}{l}\text { PEP+: } 16 / 50 \text { (32.0\%) } \\
\text { Orchidectomy: } 23 / 56(41.1 \%) \\
\text { Radiotherapy: } 9 / 45 \text { (20.0\%) }\end{array}$ & NR & $\begin{array}{l}\text { PEP+: I8/50 (36.0\%), } 5 \text { fatal } \\
\text { (10\%) } \\
\text { Orchidectomy: I3/56 (23.2\%), } \\
6 \text { fatal ( } 10.7 \%) \\
\text { Radiotherapy: } 6 / 45 \text { (22.2\%), } \\
3 \text { fatal (11.1\%) }\end{array}$ & $\begin{array}{l}\text { Inappropriate randomisation } \\
\text { (date of birth) }\end{array}$ \\
\hline $\begin{array}{l}\text { Johansson et al } \\
(199 \mid a, b)\end{array}$ & 150 & Orchidectomy & $\begin{array}{l}7-10 \text { years } \\
(5 \text { years for survival } \\
\text { data) }\end{array}$ & $\begin{array}{l}\text { PEP+: 54/74 (73.0\%) } \\
\text { Orchidectomy: 54/76 (71.1\%) }\end{array}$ & $\begin{array}{l}\text { PEP+: } 27 / 74(36.5 \%) \\
\text { Orchidectomy: } 36 / 76 \\
(47.4 \%)\end{array}$ & $\begin{array}{l}\text { PEP+: } 36 / 74 \text { (48.6\%), I3 fatal } \\
\text { (17.6\%) } \\
\text { Orchidectomy: 13/76 (17.1\%), } \\
9 \text { fatal (11.8\%) }\end{array}$ & $\begin{array}{l}\text { Inappropriate randomisation } \\
\text { (date of birth) }\end{array}$ \\
\hline $\begin{array}{l}\text { Henriksson and } \\
\text { Edhag (1986); } \\
\text { Henriksson and } \\
\text { Johansson (1987) }\end{array}$ & $91 / 100$ & Orchidectomy & $\geqslant 1$ year & NR & NR & $\begin{array}{l}\text { Major CVS events } \\
\text { PEP+: I } 3 / 53 \text { (24.5\%) } \\
\text { Orchidectomy: 0/47 (0\%) }\end{array}$ & $\begin{array}{l}9 \text { non-randomised patients } \\
\text { included }\end{array}$ \\
\hline Daehlin et al (1986) & 30 & $\begin{array}{l}\text { (1) Estramustine phosphate } \\
9.2 \mathrm{mg} \mathrm{kg}^{-1} \text { day }{ }^{-1} \text { b.i.d., p.o } \\
\text { (2) Orchidectomy }\end{array}$ & 6 months & NR & NR & $\begin{array}{l}\text { PEP+: I/IO (I0\%), } 0 \text { fatal (0\%) } \\
\text { Estramustine phosphate: } 3 / 10 \\
(30 \%) \text {, I fatal (10\%) } \\
\text { Orchidectomy: } 0 / 10(0 \%)\end{array}$ & $\begin{array}{l}\text { Insufficient information to } \\
\text { assess }\end{array}$ \\
\hline \multicolumn{8}{|c|}{ Ig Stilboestrol i.v. every 2 weeks plus $50 \mathrm{mg} \mathrm{m}^{-2}$ doxorubicin every 3 weeks $^{\mathrm{a}}$} \\
\hline Leaf et al (2003) & 188 & $\begin{array}{l}\text { Doxorubicin } 50 \mathrm{mg} \mathrm{m}^{-2} \\
\text { every } 3 \text { weeks }\end{array}$ & $>5$ years & $\begin{array}{l}\text { Median survival: } \\
\text { PEP+: } 8.5 \text { months } \\
\text { Doxorubicin: } 7.7 \text { months }\end{array}$ & NR & $\begin{array}{l}\text { PEP+: } 13.5 \%, 1.4 \% \text { fatal } \\
\text { Doxorubicin: } 1.3 \%, 0 \% \text { fatal }\end{array}$ & $\begin{array}{l}\text { Insufficient information to } \\
\text { assess }\end{array}$ \\
\hline
\end{tabular}

CVS = cardiovascular system; $N=$ number of patients; $N R=$ not reported; PEP = polyoestradiol phosphate; PEP+ = PEP combined with oral oestrogen. Studies are ordered by sample size within dosage categories. Since increased cardiovascular risk occurs primarily during the first 2 years of oestrogen therapy, where trials report CVS events for more than one follow-up period, those closest to 2 years are given. In some trials, participants may have had higher initial treatment doses or may have received other additional treatment. The dose given here is the routine dose given for the duration of the trial. Further details can be found in the full evidence tables (see Appendix 7 of CRD report). 
Table 4 Included studies comparing parenteral oestrogen given at different doses

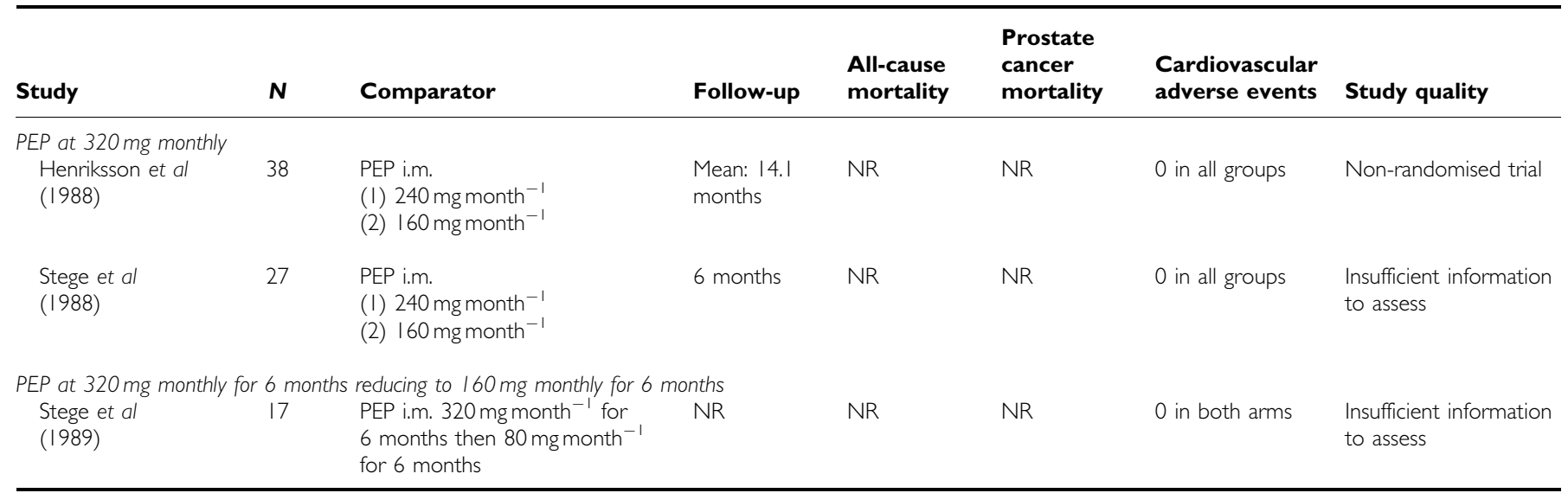

$N=$ number of patients; $N R=$ not reported; PEP = polyoestradiol phosphate. Studies are ordered by sample size within dosage categories.

(240 $\left.\mathrm{mg} \mathrm{month}^{-1}\right)$, including two large recent RCTs, one of which was of good methodological quality. There was variation in the patient populations of these three studies, in particular, the proportion of patients with metastatic disease (all patients in the Hedlund trial had metastatic disease compared to less than half of patients in the Mikkola trial). The comparator arm was a mixed LHRH/orchidectomy arm in the Hedlund trial and orchidectomy alone in the other two trials. In addition, the analysis in the Mikkola trial was based on 10-year follow-up, although some data from 2-year follow-up were also included in the review. The Hedlund trial analysis was based on patients who had died within 7 years after the start of the trial with a median follow-up of 27 months; although data at 12-year follow-up have now been analysed, the report is currently only available in abstract form. A 24-month follow-up was reported in the Henriksson trial. Given the variation in study populations and outcomes, it was decided that it would not be meaningful to statistically pool these studies.

\section{Effectiveness}

The randomised trials included in the review provided no clear evidence that parenteral oestrogen alone, at doses sufficient to produce castrate levels of testosterone, differed in effectiveness from LHRH analogues or orchidectomy in terms of prostate cancer mortality or overall mortality.

\section{Adverse events}

The included studies also provided no consistent evidence that the incidence of fatal cardiovascular events with parenteral oestrogen alone is different to that reported with LHRH analogues or orchidectomy. Where there is evidence of excess mortality, the data suggest that it may be confined to those patients who have non-metastatic disease and to patients with pretreatment vascular disease; patients with other pretreatment disease associated with the risk of CVS events do not appear to incur a similar risk for excess mortality with PEP therapy (but the exclusion of, for example, hypertension and cardiac heart failure as high risk for CVS events may be considered contentious). However, there is clearer evidence of increased cardiovascular morbidity with parenteral oestrogen alone, although the seriousness of non-fatal adverse events was often not reported and criteria for recording an event were often unclear.

Such CVS risks should be balanced against the risks of non-CVS adverse events resulting from LHRH analogues or orchidectomy such as osteoporosis and osteoporotic fracture; these were reported in only one of the trials included in the review, which did show an increased rate of skeletal adverse events in the combined ADT arm (Hedlund et al, 2007). Other potential adverse events of LHRH analogues were not reported in any of the included studies. This lack of evidence on adverse events associated with standard hormone treatment may result partly from the relatively short follow-up times used in many of the studies, but also suggests that such events were not considered in the study design. Standard hormone treatment results in high levels of osteoporosis and, consequently, of osteoporotic fracture with a mortality rate of approximately $15 \%$ in the first year, although this has been reported to be as high as 35\% (Center et al, 1999). Incidence of osteoporotic fracture should be an outcome measure for safety in any future trial.

Long-term follow-up is also of importance in risk assessment, given that there are indications that the effect of parenteral oestrogen on the incidence of CVS events may not be monotonic. For women on hormone replacement therapy, increased CVS risk over the first 2 years has been observed. Thereafter, CVS benefit accrues, such that the risk of CVS events is reduced by $30-50 \%$ after 10 years on treatment (Hulley et al, 1998; Grodstein et al, 2001). Similar changes may occur in men (Aro, 1991; Ockrim JL et al, 2006). This pattern of risk may result from changes in arterial compliance caused by oestrogen therapy. During the early months of oestrogen therapy, arterial compliance is reduced and cardiac demands increased. Thereafter, arterial compliance adapts leading to improved CVS dynamics (Turgeon et al, 2004). However, the Mikkola study examined the incidence of CVS events and found that the rate of occurrence did not diminish significantly over the first 3 years of treatment. Instead, the risk remained higher among men with non-metastatic disease in the PEP group than in the orchidectomy group, but did not differ between groups for those with metastatic disease (Mikkola et al, 2005).

\section{Costs}

No economic evaluations were found. In addition to the cost of treatment regimes, the economic impact of the adverse events associated with alternative treatments requires evaluation. The annual cost of osteoporotic fractures in men in the United Kingdom has been estimated at $£ 236$ million (Pande and Francis, 2001). A previous economic evaluation of LHRH analogues has indicated that they are a cost-effective alternative to orchidectomy, but this is a hormonally equivalent treatment, which also results in 
the andropause (Aronson et al, 1999). A subsequent evaluation indicated that LHRH-based therapy was more cost-effective than orchidectomy or DES if initiated only after development of metastases (Bayoumi et al, 2000). One estimate suggests that hormonal therapy accounts for more than two-thirds of the total cost of prostate cancer, approximately $£ 63.1$ million for patients diagnosed during 2001-2002 in the United Kingdom (Sangar et al, 2005). These costs increase substantially with the addition of antiandrogens or bisphosphonates. In contrast, oestrogen patches cost approximately one-tenth the price of LHRH analogues (Ockrim J et al, 2006). Alternative transcutaneous administration using cream or gel is likely to be comparable in cost to that of patches.

\section{CONCLUSION AND FUTURE RESEARCH}

Because of the paucity of good quality evidence, it is not possible to draw any clear conclusion on the effectiveness and safety of parenteral oestrogen compared with other hormone therapy. The results of this systematic review provide no evidence to suggest that parenteral oestrogen, in doses sufficient to produce castrate levels of testosterone, is less effective than LHRH or orchidectomy in controlling prostate cancer, or that it is associated with an increase in cardiovascular mortality. There is, therefore, a need for further research into the use of parenteral oestrogen as an alternative to existing hormone treatments for prostate cancer, which are associated with a number of side effects and high costs. Evaluation of parenteral oestrogen, involving direct comparison of the adverse event profile with that of LHRH analogues including, but not limited to, osteoporotic events, is needed. Particular attention should be paid to the issue of clearly defining and accurately assessing cardiovascular morbidity as well as mortality, especially in relation to a patient's existing cardiovascular disease status, particularly their history of vascular disease, and the metastatic status of their prostatic cancer. Patients' acceptability and quality of life issues should also be examined, along with a full economic evaluation. A pilot RCT of transcutaneous oestrogen patches $v s$ LHRH analogues in prostate cancer is currently underway (Abel, ongoing). The primary objective of this study is to confirm that oestrogen patches are a safe and efficacious therapy for patients with locally advanced and metastatic prostate cancer.

\section{REFERENCES}

Abel P. PATCH: a randomised controlled trial of transcutaneous oestrogen patches versus LHRH analogues in prostate cancer, Vol 2007. National Research Register (ongoing)

Andersson L, Berlin T, Boman J, Collste L, Edsmyr F, Esposti PL, Gustafsson H, Hedlund PO, Hultgren L, Leander G, Nordle O, Norlen H, Tillegard P (1980) Estramustine versus conventional estrogenic hormones in the initial treatment of highly or moderately differentiated prostatic carcinoma. A randomized study. Scand J Urol Nephrol 55(Suppl): $143-145$

Aro J (1991) Cardiovascular and all-cause mortality in prostatic cancer patients treated with estrogens or orchiectomy as compared to the standard population. Prostate 18: $131-137$

Aro J, Haapiainen R, Kajanti M, Rannikko S, Alfthan O (1988) Comparison of endocrine and radiation therapy in locally advanced prostatic cancer. Eur Urol 15: $182-186$

Aro JL, Haapiainen RK, Rannikko SA, Alfthan OS (1989) High dose polyoestradiol phosphate with and without acetosalicylic acid versus orchiectomy in the treatment of prostatic cancer. Finnprostate Group. Br J Urol 63: 512-514

Aro J, Ruutu M, Juusela H, Hansson E, Permi J (1993) Polyestradiol phosphate $(160 \mathrm{mg} / \mathrm{month})$ or LHRH analog (buserelin depot) in the treatment of locally advanced or metastasized prostatic cancer. Ann Chir Gynaecol 82(Suppl 206): 5-8

Aronson N, Seidenfeld J, Samson DJ, Albertson PC, Bayoumi AM, Bennett C, Brown A (1999) Relative Effectiveness and Cost-effectiveness of methods of Androgen Suppression in the Treatment of Advanced Prostate Cancer. Vol 4. Evidence Report/Technology Assessment. Rockville, MD: Agency for Health Care Policy and Research

Bayoumi AM, Brown AD, Garber AM (2000) Cost-effectiveness of androgen suppression therapies in advanced prostate cancer. J Natl Cancer Inst 92: $1731-1739$

Bishop MC, Lemberger RJ, Selby C, Lawrence WT (1989) Oestrogen dosage in prostatic cancer: the threshold effect? Br J Urol 64: 290-296

Byar DP (1973) The Veterans' Administration Cooperative Urological Research Group's study of cancer of the prostate. Cancer 32: $1126-1130$

Cancer Research UK (2007) UK prostate cancer statistics. London: Cancer Research UK (cited 22 January 2008). Available at: http://info. cancerresearchuk.org/cancerstats/types/prostate/

Center JR, Nguyen TV, Schneider D, Sambrook PN, Eisman JA (1999) Mortality after all major types of osteoporotic fracture in men and women: an observational study. Lancet 353: 878-882

Daehlin L, Damber JE, Von Schoultz B, Bergman B (1986) The oestrogenic effects of ethinyl oestradiol/polyoestradiol phosphate and estramustine phosphate in patients with prostatic carcinoma. A comparative study of oestrogen sensitive liver proteins, gonadotrophins and prolactin. $\mathrm{Br} J$ Urol 58: $412-416$
D'Amico AV, Denham JW, Crook J, Chen M-H, Goldhaber SZ, Lamb DS, Joseph D, Tai K-H, Malone S, Ludgate C, Steigler A, Kantoff PW (2007) Influence of androgen suppression therapy for prostate cancer on the frequency and timing of fatal myocardial infarctions. J Clin Oncol 25: $2420-2425$

Dean ME, Norman G, Hodges Z, Ritchie G, Light K, Eastwood A, Langley R, Sydes M, Parmar M, Abel P (2006) Parenteral Oestrogens for Prostate Cancer: A Systematic Review of Clinical Effectiveness and Dose Response. York: Centre for Reviews and Dissemination, University of York

Grodstein F, Manson JE, Stampfer MJ (2001) Postmenopausal hormone use and secondary prevention of coronary events in the nurses' health study. A prospective, observational study. Ann Intern Med 135: 1-8

Haapiainen R, Rannikko S, Alfthan O (1986) Comparison of primary orchiectomy with oestrogen therapy in advanced prostatic cancer. A 2-year follow-up report of a national, prospective prostatic cancer study. Br J Urol 58: $528-533$

Haapiainen R, Rannikko S, Alfthan O (1990) Comparison of primary orchiectomy and polyoestradiol phosphate in the treatment of advanced prostatic cancer. Finnprostate Group. Br J Urol 66: 94-97

Haapiainen R, Rannikko S, Ruutu M, Ala-Opas M, Hansson E, Juusela H, Permi J, Saarialho M, Viitanen J, Alfthan O (1991) Orchiectomy versus oestrogen in the treatment of advanced prostatic cancer. Br J Urol 67: $184-187$

Hedlund PO, Ala-Opas M, Brekkan E, Damber JE, Damber L, Hagerman I, Haukaas S, Henriksson P, Iversen P, Pousette A, Rasmussen F, Salo I, Vaage S, Varenhorst E, Scandinavian Prostatic Cancer Group (2002) Parenteral estrogen versus combined androgen deprivation in the treatment of metastatic prostatic cancer. Scandinavian Prostatic Cancer Group (SPCG) Study no. 5. Scand J Urol Nephrol 36: 405-413

Hedlund PO, Mikkelsen I, Hahne B, Kihl B (2007) Parenteral estrogen vs. combined androgen deprivation in the treatment of metastatic prostate cancer. The final evaluation of the SPCG study. [abstract]. Scand J Urol Nephrol 41(Suppl 217): Abstract

Henriksson P, Carlstrom K, Pousette A, Gunnarsson PO, Johansson CJ, Eriksson B, Altersgard-Brorsson AK, Nordle O, Stege R (1999) Time for revival of estrogens in the treatment of advanced prostatic carcinoma? Pharmacokinetics, and endocrine and clinical effects, of a parenteral estrogen regimen. Prostate 40: $76-82$

Henriksson P, Edhag O (1986) Orchidectomy versus oestrogen for prostatic cancer: cardiovascular effects. BMJ 293: 413-415

Henriksson P, Eriksson A, Stege R, Collste L, Pousette A, von Schoultz B, Carlstrom K (1988) Cardiovascular follow-up of patients with prostatic cancer treated with single-drug polyestradiol phosphate. Prostate 13: $257-261$

Henriksson P, Johansson SE (1987) Prediction of cardiovascular complications in patients with prostatic cancer treated with estrogen. Am J Epidemiol 125: $970-978$ 
Hulley S, Grady D, Bush T, Furberg C, Herrington D, Riggs B (1998) Randomized trial of estrogen plus progestin for secondary prevention of coronary heart disease in postmenopausal women. Heart and Estrogen/ progestin Replacement Study (HERS) Research Group. JAMA 280: 605-613

Jacobi GH, Altwein JE, Kurth KH, Basting R, Hohenfellner R (1980) Treatment of advanced prostatic cancer with parenteral cyproterone acetate: a phase III randomised trial. Br J Urol 52: 208-215

Jadad AR, Moore A, Carroll D, Jenkinson C, Reynolds JM, Gavaghan DJ, McQuay HJ (1996) Assessing the quality of reports of randomized clinical trials: is blinding necessary? Control Clin Trials 17: 1-12

Johansson JE, Andersson SO, Holmberg L, Bergstrom R (1991a) Prognostic factors in progression-free survival and corrected survival in patients with advanced prostatic cancer: results from a randomized study comprising 150 patients treated with orchiectomy or estrogens. J Urol 146: $1327-1333$

Johansson JE, Andersson SO, Holmberg L, Bergstrom R (1991b) Primary orchiectomy versus estrogen therapy in advanced prostatic cancer - a randomized study: results after 7-10 years of followup. J Urol 145: $519-523$

Keating NL, O’Malley AJ, Smith MR (2006) Diabetes and cardiovascular disease during androgen deprivation therapy for prostate cancer. J Clin Oncol 24: $4448-4456$

Krupski TL, Smith MR, Chan Lee W, Pashos CL, Brandman J, Wang Q, Botteman M, Litwin MS (2004) Natural history of bone complications in men with prostate carcinoma initiating androgen deprivation therapy. Cancer 101: $541-549$

Leaf AN, Propert K, Corcoran C, Catalano PJ, Trump DL, Harris JE, Davis TE (2003) Phase III study of combined chemohormonal therapy in metastatic prostate cancer (ECOG 3882): an Eastern Cooperative Oncology Group study. Med Oncol 20: 137-146

Lukkarinen O, Kontturi M (1994) Comparison of a long-acting LHRH agonist and polyoestradiol phosphate in the treatment of advanced prostatic carcinoma. An open prospective, randomized multicentre study. Scand J Urol Nephrol 28: 171-178

Lundgren R, Nordle O, Josefsson K, The South Sweden Prostate Cancer Study Group (1995) Immediate estrogen or estramustine phosphate therapy versus deferred endocrine treatment in nonmetastatic prostate cancer: a randomized multicenter study with 15 years of follow-up. J Urol 153: $1580-1586$

Mikkola A, Aro J, Rannikko S, Oksanen H, Ruutu M, Finnprostate Group (2005) Cardiovascular complications in patients with advanced prostatic cancer treated by means of orchiectomy or polyestradiol phosphate. Scand J Urol Nephrol 39: 294-300

Mikkola A, Aro J, Rannikko S, Ruutu M, Finnprostate G (2007) Ten-year survival and cardiovascular mortality in patients with advanced prostate cancer primarily treated by intramuscular polyestradiol phosphate or orchiectomy. Prostate 67: $447-455$

Mikkola AK, Ruutu ML, Aro JL, Rannikko SA, Salo JO (1998) Parenteral polyoestradiol phosphate $v s$ orchidectomy in the treatment of advanced prostatic cancer. Efficacy and cardiovascular complications: a 2-year follow-up report of a national, prospective prostatic cancer study. Finnprostate Group. Br J Urol 82: 63-68

Morganstein N, Doyle-Lindrud S, Goodin S, Shih J, Altscher A, Teller E, Zager R, Todd M, Durivage H, Dipaola RS (2004) A phase II salvage trial of transdermal estradiol in the treatment of hormone and chemotherapy refractory prostate cancer: a Cancer Institute of New Jersey Oncology Group Study NJ1803. J Clin Oncol, 2004 ASCO Annual Meeting Proceedings (Post-Meeting Edition) 22(14S): 4695

Ockrim J, El-Nasir L, Abel P (2006) Therapy insight: parenteral estrogen treatment for prostate cancer - a new dawn for an old therapy. Nat Clin Pract Oncol 3: $552-563$

Ockrim JL, Lalani E-N, Aslam M, Standfield N, Abel PD (2006) Changes in vascular flow after transdermal oestradiol therapy for prostate cancer: a mechanism for cardiovascular toxicity and benefit? BJU Int 97: 498-504

Ockrim JL, Lalani EN, Laniado ME, Carter SS, Abel PD (2003) Transdermal estradiol therapy for advanced prostate cancer - forward to the past? J Urol 169: $1735-1737$

Pande I, Francis RM (2001) Osteoporosis in men. Baillieres Best Pract Res Clin Rheumatol 15: 415-427

Sangar VK, Ragavan N, Matanhelia SS, Watson MW, Blades RA (2005) The economic consequences of prostate and bladder cancer in the UK. BJU Int 95: $59-63$

Sharifi N, Gulley JL, Dahut WL (2005) Androgen deprivation therapy for prostate cancer. JAMA 294: $238-244$

Steg A, Benoit G, Maisonneuve P, Tallet F, Nahoul K, Sulatna Y, Raichwarg D, Limousinlamotte MA (1983) A comparative study of percutaneous 17 beta-estradiol and diethylstilbestrol in the treatment of prostatic cancer. Ann Urol (Paris) 17: 197-202

Stege R, Carlstrom K, Collste L, Eriksson A, Henriksson P, Pousette A (1988) Single drug polyestradiol phosphate therapy in prostatic cancer. Am J Clin Oncol 11(Suppl 2): S101-S103

Stege R, Carlstrom K, Collste L, Eriksson A, Henriksson P, Pousette A, von Schoultz B (1989) Single-drug parenteral estrogen treatment in prostatic cancer: a study of two maintenance-dose regimens. Prostate 14: 183-188

Turgeon JL, McDonnell DP, Martin KA, Wise PM (2004) Hormone therapy: physiological complexity belies therapeutic simplicity. Science 304: $1269-1273$

von Schoultz B, Carlstrom K, Collste L, Eriksson A, Henriksson P, Pousette A, Stege R (1989) Estrogen therapy and liver function - metabolic effects of oral and parenteral administration. Prostate 14: 389-395 